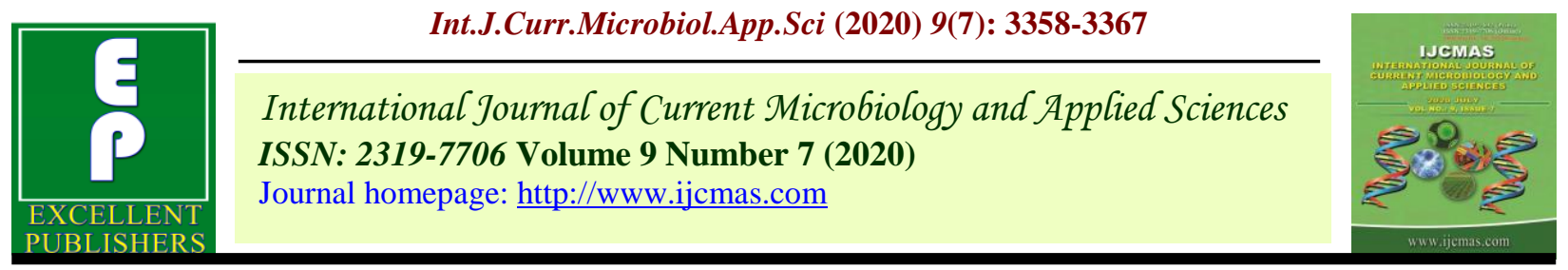

Original Research Article

https://doi.org/10.20546/ijcmas.2020.907.392

\title{
Study on Heterosis over Environments in Brinjal (Solanum melongena L.)
}

\author{
B. N. Chaudhari, A. I. Patel* and J. M. Vashi \\ Department of Vegetable Science, ASPEE College of Horticulture \& Forestry, \\ Navsari Agricultural University, Navsari - 396 450, Gujarat, India \\ *Corresponding author
}

\begin{tabular}{l}
\hline Ke y w o r d s \\
$\begin{array}{l}\text { Brinjal, Combining } \\
\text { ability, Heterosis, } \\
\text { Line x Tester }\end{array}$ \\
\hline Article Info \\
\hline $\begin{array}{l}\text { Accepted: } \\
\text { 22 June } 2020 \\
\text { Available Online: } \\
\text { 10 July } 2020\end{array}$ \\
\hline
\end{tabular}

\section{A B S T R A C T}

A total of $36 \mathrm{~F}_{1}$ hybrids were generated following line $\mathrm{x}$ tester mating design comparing of 12 lines \& 3 testers and evaluated in a RBD with three replications and three locations under the jurisdictions of Navsari Agricultural University, Navsari, Gujarat. A study was conducted on brinjal to identify superior parental combinations and to estimate the magnitude of heterosis for yield and its component traits. Higher heterosis for fruit yield per plant over commercial check was exhibited by the cross JBL-08-08 $\mathrm{x}$ NSR-1(33.47 \%) followed by AB-09-1 x NBB-1 (28.21\%), GBL - 1 x NSR -1 (23.52 \%) and GBL - $1 \times$ NBB - 1 (17.25\%). Indirect selection for traits such as plant height, number of fruits per plant, average fruit weight fruit length, fruit diameter and number of branches per plant could be done in order to achieve higher yield through heterosis breeding. The present study reveals good scope for isolation of purelines from the progenies of heterotic $\mathrm{F}_{1} \mathrm{~s}$ as well as commercial exploitation of heterosis in brinjal.

\section{Introduction}

Brinjal (Solanum melongena L.) holds an important place in China, India, Japan and Europe. Brinjal also known as eggplant belonging to the family Solanaceae is one of the most important vegetable crops grown in India and other parts of the world. In India, its cultivation is scattered all over the country especially in Tamil Nadu, Karnataka, Andhra Pradesh, Maharashtra, Rajasthan and Gujarat. It is grown throughout the year under tropical and subtropical conditions and usually finds its place in common men's kitchen. Being a centre of origin, Brinjal has a huge genetic divergence in our country which offers much scope for improvement through heterosis breeding. The effort could enhance its quality and productivity without sacrificing the consumers' choice. Though, the improvement work in brinjal started as early as 1900s but it took long time to start with concentrated efforts on genetic improvement and still exploration for a better cultivar is going on, as 
most of the commercial cultivars lack one or the other desirable traits (Prabhakaran, 2010). In India, productivity of eggplant is low as compared to the other eggplant growing countries, owing to use of low yielding cultivars grown for local preference and their susceptibility to pests and diseases.

The present production, however, is not proportionate to the country demand. Therefore, the crop deserves a deep deliberation for improvement. The effort could enhance its quality and productivity without sacrificing the consumer's choice. The required goals of increasing productivity in the quickest possible time can be achieved only through heterosis breeding which is feasible in this crop. Exploitation of hybrid vigour has become a potential tool for improvement in eggplant. Nagai and Kada (1926) were the first to observe hybrid vigour in brinjal. The commercial exploitation of this phenomenon has been possible in the brinjal because of the low cost of $F_{1}$ seed production and the low seed requirement per unit area. With increasing popularity of $F_{1}$ hybrids in Brinjal, it is imperative to obtain such hybrids, having excellent quality coupled with high yields. In crop manifestation of heterotic effect for different economically important characters have been reported by many scientists (Joshi and Thakur, 2003; Ajjappalavara, 2006; Sao and Maheta 2010; Kumar et al., 2012; Makani et al., 2013, Sharma et al., 2016; Pramila et al., 2017 and Kalaiyarasi et al., 2018). Therefore, the present investigation was undertaken to identify the potential combinations in order to have superior hybrids of excellent qualities coupled with high yields for various characters in brinjal.

\section{Materials and Methods}

A total of $36 \mathrm{~F}_{1}$ hybrids generated following Line $\mathrm{x}$ Tester mating design comparing of 12 lines and 3 testers were evaluated. The experimental material for this study comprised of 15 genotypes which were selected based on their diversity for various traits. Among the genotypes, three viz., NSRP- 1, NBB - 1 and NSR-1 (Surati Ravaiya) were used as male (testers) and twelve advanced breeding lines viz., AB -072, AB -08- 5, AB -08- 14, JBL -08- 08, JBL 10- 04, JBGR- 1, GBL - 1, GJB - 2, AB- 08 $-6, \mathrm{AB}-10-14, \mathrm{AB}-09-1$ and $\mathrm{AB}-11-8$ were used as female parent (lines). All the genotypes were grown at Regional Horticulture Research Station, ASPEE College of Horticulture and Forestry, Navsari Agriculture University, Navsari and crossed in line $\mathrm{x}$ tester matting design for producing thirty-six crosses.

All crosses along with their parents were evaluated at three different locations viz., Regional Horticulture Research Station, Navsari, Main Cotton Research Station, Surat and Cotton Wilt Testing Research Station, Hansot, NAU, Navsari, Gujarat in a randomized block design (RBD) with three replication with spacing of $75 \mathrm{~cm} \mathrm{x} 60 \mathrm{~cm}$. Standard package of practices were followed to raise the crop.

Data were recorded on five randomly selected plants in each treatment over replication for all the characters viz., seedling height $(\mathrm{cm})$, plant height $(\mathrm{cm})$, number of branches per plant, days to $50 \%$ flowering, average fruit weight $(\mathrm{g})$, average fruit length $(\mathrm{cm})$, average fruit diameter $(\mathrm{cm})$, number of fruits per plant, fruit yield per plant $(\mathrm{g})$, test weight $(\mathrm{g})$, number of seeds per fruit, fruit dry matter $(\mathrm{g})$, total soluble sugar (per cent), and ascorbic acid (mg/100). The statistical analysis was done as per Panse and Sukhatme (1985) and magnitude of per cent heterosis in hybrids over standard check was calculated as per procedure suggested by Fonseca and Patterson (1968). 


\section{Results and Discussion}

The pooled analysis of variance revealed significant mean square for genotype parents and hybrids indicated the presence of adequate variability. The mean squares due to parents vs. hybrids revealed significant for all the traits except plant height, days to 50 percent flowering, average fruit length and total soluble sugar these indicating the presence of heterosis for these traits. The variance due to hybrids was highly significant for all the traits under individual environments as well as in pooled analysis signifying substantial variation among hybrids. The parents vs. hybrids $\mathrm{X}$ environments interactions were nonsignificant for seven traits viz., plant height, number of branches per plant, days to 50 per cent flowering, average fruit length, test weight, number of seeds per fruit and total soluble sugar indicated that environment had less influence on these traits. The interactions of hybrids $\mathrm{x}$ environments were significant for all the traits except days to 50 per cent flowering, suggesting the differential behaviour of hybrids in different environments.

In the present investigation, a total of four crosses exhibited highly significant standard heterosis for fruit yield on pooled basis while the highest being the cross JBL-08-08 x NSR1 (33.47 per cent) (Table 2). The standard heterosis was ranged from -29.96 to 33.47 per cent for fruit yield in pooled analysis (Table 2). The maximum standard heterosis recorded by JBL-08-08 x NSR-1 was 33.47 per cent followed by AB-09-1 x NBB-1 (28.21 per cent), GBL-1 x NSR-1 (23.52 per cent) and GBL-1 x NBB-1 (17.25 per cent) (Table 2) for fruit yield. Such reports were in collaboration with reports of Biswas et al., (2013), Makani et al., (2013), Reddy and Patel (2014), Deshmukh et al., (2015), Ramani et al., (2015) and Sharma et al.,
(2016). Four crosses reported highly significant and positive standard heterosis for fruit yield which is appearing to be due to the diversity among the parents involved. The result are closer agreement with the findings of Biswas et al., (2013), Makani et al., (2013), Reddy and Patel (2014), Deshmukh et al., (2015), Ramani et al., (2015) and Pandey and Yadav (2018). Singh and Murty (1971) reported that genetic diversity between the parents play a key role in the expression of heterosis result also indicated that the magnitude of heterosis was higher for morphological characters than quality characters. High level of heterosis in cross resulted mainly due to vegetative superiority of such hybrids during initial growth period resulting in high fruiting potential. This indicated ample scope for evolving commercial hybrids than pure line varieties. Similar findings have been reported by Reddy and Patel (2014).

Component wise examination of the crosses revealed that the top yielding cross JBL-08-08 $x$ NSR-1 manifested high heterosis for number of fruits per plant, a major yield component (Table 3) (Makani et al., (2013), Reddy and Patel (2014), Deshmukh et al., (2015), Ramani et al., (2015), Sharma et al., (2016) and Kalaiyarasi et al., (2018)). However, in some crosses viz., AB-07-2 $\mathrm{x}$ NSRP-1, AB-08-5 x NBB-1, AB-08-5 x NSR-1, JBL-08-08 x NSR-1, JBL-10-4 x NSR-1, JBGR-1 x NSRP-1, JBGR-1 x NBB1, JBGR-1 x NSR-1, AB-10-14 x NSRP-1 and AB-10-14 x NBB-1 though considerable heterosis was observed for number of fruits per plant but they did not exhibit high heterosis for fruit yield per plant (Table 2). The low heterosis exhibited by the above crosses is due to fruit weight and number of fruits per plant. This indicated that the yield is a very complex character and depends upon interrelationship among various component characters. Almost identical result have been 
reported by Reddy and Patel (2014), Deshmukh et al., (2015) and Ramani et al., (2015). It is also interesting to note that these highly heterotic crosses did not exhibited significant heterosis for any of the other important yield component like fruit weight, number of seeds per fruit and average fruit length. On the contrary, some of these crosses exhibited significant and negative heterosis for these characters. Similar findings were reported by Prabhu et al., (2005). In top yielding crosses, there was no consistency with regard to the relationship between heterosis for number of fruits per plant and that for fruit yield as observed in some crosses. This is due to interacting effects of different components in manifestation of heterosis for fruit yield. It is therefore, suggested that for getting higher yields from F1hybrids, parents which can compensate each other for main yield component especially average fruit weight should be involved. Such reports were in collaboration with Makani et al., (2013), Reddy and Patel (2014), Deshmukh et al., (2015) and Ramani et al., (2015).

Out of these four top yielding crosses, only one cross JBL-08-08 x NSR-1 showed significant and positive heterosis for number of fruits per plant (Table 2). This result revealed that number of fruits per plant may not be considerable as major yield components in brinjal. Almost identical results have been reported by Chowdhury et al., (2010).

The number of branches per plant is one of the major parameter contributing for total fruit yield per plant (Table 1). All the four crosses showed significant and positive standard heterosis for number of branches per plant except one crosses GBL-1 x NBB-1 (Table 3). The higher number of branches might be resulted into more number of fruits which resulted in higher fruit yield. Makani et al., (2013), Reddy and Patel (2014), Deshmukh et al., (2015), Ramani et al., (2015) and Pandey and Yadav (2018) made similar observation in brinjal.

Seedling height in terms of early vigour is highly desired for the better crop establishment and good stand against competing weeds. A total of four top yielding crosses showed significant and standard positive heterosis for seedling height and plant height (except AB-09-1 x NBB-1and GBL-1 x NSR-1 in seedling height) (Table 3). This result due to higher seedling height in early stage might be increasing plant height also and it resulted into higher number of branches per plant which converted higher number of traits and yield also. Similar results have been reported by Reddy and Patel (2014), Deshmukh et al., (2015), Ramani et al., (2015) and Pandey and Yadav (2018).

Fruit length is an important parameter of fruit deciding consumer preference, while, fruit diameter is another important character as that of fruit length. In south Gujarat, higher fruit length and fruit weight were not preferred. Therefore, the character showing negative heterosis is very useful. All the four top yielding crosses viz., JBL-08-08 x NSR-1, AB-09-1 x NBB-1, GBL-1 x NSR-1 and GBL-1 $x$ NBB-1 showed significant and negative standard heterosis for average fruit weight and average fruit length (Table 1). Hence, these characters were as important as number of branches per plant. These findings were in agreement with the findings reported by Reddy and Patel (2014), Deshmukh et al., (2015) and Ramani et al., (2015).

Early flowering is generally an indication of early yield (Yordanor, 1983) and also early hybrids fit well in multiple cropping systems (Kamalakannan et al., 2007). For this trait negative heterosis is to be considered as desirable (Table 1). Out of four top yielding 
crosses, only one cross GBL-1 x NBB-1 recorded significant and negative heterosis over standard check for this trait, while the other three crosses dose not showed standard heterosis in desirable direction indicated that this character could not play a vital role in fruit yield in brinjal. This result are agreement with Makani et al., (2013), Reddy and Patel (2014), Deshmukh et al., (2015), Ramani et al., (2015), Sharma et al., (2016), Pramila et al., (2017) and Pandey and Yadav (2018). The reason for significant negative heterosis may be due to the presence of dominant loci in different direction leading to cancellation of effect. The crosses showing no higher heterosis indicated that the parents involved in the cross do not differ in gene frequency with respect to character under study (Pandey et al., 2005).

Fruit diameter is another important character as that of fruit length in south Gujarat region (Table 1). Higher fruit length and higher fruit diameter is not preferred therefore, the crosses showing negative heterosis are useful. Out of the four top yielding crosses, none of the crosses showed significant and negative standard heterosis for this trait. Out of 36 crosses, a total of 24 crosses showed significant and negative heterosis over check, of which, only one cross JBL-10-4 x NBB-1 showed significant and negative standard heterosis coupled with standard heterosis for fruit yield in desirable direction. This findings were in agreement with the findings reported by Reddy and Patel (2014), Deshmukh et al., (2015) and Ramani et al., (2015).

There is a biological balance between the principle yield components, number of fruits on one hand and average fruit weight, fruit length, fruit diameter, test weight and number of branches per plant on other hand, for high heterotic expression of yield. It is evident from the result that it is not necessary that high heterosis for all the yield components only will result in high heterosis for yield but increase in any one or two yield components may also results in to high degree of heterosis for yield. In this experiment, all the top four high yielding crosses exhibited significant heterosis against average fruit weight. Almost identical results have been reported by Makani et al., (2013), Reddy and Patel (2014), Deshmukh et al., (2015), Ramani et al., (2015) and Pandey and Yadav (2018).

All the top yielding crosses showing significant and negative heterosis over standard check for test weight (Table 2)while, only one cross JBL-1 x NSR-1 showed significant and negative heterosis over standard check for number of seeds per fruit (Table 3). Similarly results have been reported by Suneetha et al., (2008).

Brinjal is known to have low sugar content and thereby it has low calorie value (Ankita et al., (2014)). The Total soluble sugars was found in the range of -31.46 (JBL-10-4 $\mathrm{x}$ NSRP-1) to -0.28 per cent (JBGR-1 x NSR-1) in pooled analysis (Table 3). In present experiment, the sugar contain in the range of 20 to 30 per cent on dry matter basis. Similar results have been reported by Hanson et al., (2006). All the four top crosses sowing significant and negative heterosis for total soluble sugars. Similar result have been reported by Suneetha et al., (2008), and Biswas et al., (2013).

From the nutrient point of view, quality is considered as an important factor in any vegetable crop. Brinjal being a commercial and popular vegetable in India and Gujarat, it is needless to emphasise the importance of quality parameter for consumption of fresh and processed produce. Generally, the higher ascorbic acid content would increase the nutritive value of the fruits (Table 2), which would help better retention of colour and flavour (Sasikumar, 1999). 
Table.1 The estimation of standard heterosis over environments (pooled) for different characters

\begin{tabular}{|c|c|c|c|c|c|c|c|c|}
\hline HYBRIDS & 1 & 2 & 3 & 4 & 5 & 6 & 7 & 8 \\
\hline AB -07- 2 X NSRP- 1 & $-11.62 * *$ & 2.93 & -8.92 & $-6.51 * *$ & $-16.58 * *$ & 4.52 & $-21.78 * *$ & $19.32 * *$ \\
\hline AB -07- 2 X NBB - 1 & 3.57 & $16.06^{*}$ & -2.55 & $-5.75 * *$ & $-13.29 * *$ & -2.62 & $-28.25 * *$ & 1.13 \\
\hline AB -07- 2 X NSR - 1 & 6.70 & 16.10 & $17.33^{*}$ & -1.34 & 1.12 & 4.58 & -11.44 & -5.75 \\
\hline AB -08- 5 X NSRP- 1 & 1.13 & $17.52 *$ & 3.47 & $-5.75 * *$ & $-13.11 * *$ & -9.97 & $-22.73 * *$ & 9.11 \\
\hline AB -08- 5 X NBB - 1 & -1.70 & -9.80 & 12.19 & $-4.41 *$ & $-33.34 * *$ & -8.20 & $-27.19 * *$ & $22.61 * *$ \\
\hline AB -08- 5 X NSR - 1 & -6.25 & 13.95 & 7.72 & -1.92 & $-23.58 * *$ & 1.16 & $-18.59^{*}$ & $23.90 * *$ \\
\hline AB -08- 14 X NSRP- 1 & -14.50 & -0.34 & 3.25 & $-5.56 * *$ & 0.06 & -17.97 & -9.73 & 3.26 \\
\hline AB -08- 14 X NBB - 1 & -3.39 & 8.94 & $19.84 * *$ & -0.19 & -8.71 & 9.08 & $-20.41 * *$ & 6.74 \\
\hline AB -08- 14 X NSR - 1 & $-9.42 * *$ & 9.01 & 3.84 & -0.57 & $-12.32 * *$ & 11.47 & $-23.34 * *$ & 7.74 \\
\hline JBL -08- 08 X NSRP- 1 & $9.40 * *$ & $22.59 * *$ & $12.43 * *$ & $-9.58 * *$ & $23.76 * *$ & $30.65 * *$ & 5.66 & -10.63 \\
\hline JBL -08- 08 X NBB - 1 & 4.69 & 6.52 & 6.94 & 1.34 & $13.03 * *$ & $-20.50 * *$ & $-24.11 * *$ & $-19.79 * *$ \\
\hline JBL -08- 08 X NSR - 1 & $11.88^{* *}$ & $15.27 *$ & $21.43^{* *}$ & -1.92 & $12.24 * *$ & $42.63 * *$ & 13.52 & $20.78 * *$ \\
\hline JBL -10- 04 X NSRP- 1 & -3.34 & 13.31 & 7.66 & 1.92 & -9.88 & -13.82 & $-42.99 * *$ & 8.65 \\
\hline JBL -10- 04 X NBB - 1 & $-10.58 *$ & $16.62 *$ & $13.52 *$ & 0.77 & 1.29 & -18.96 & $-23.22 * *$ & 11.98 \\
\hline JBL -10- 04 X NSR - 1 & -0.28 & -4.93 & 0.34 & -3.64 & -3.42 & -11.94 & -11.42 & $21.63 * *$ \\
\hline JBGR- 1 X NSRP- 1 & 3.30 & 7.19 & 12.32 & 0.96 & $-32.04 * *$ & 1.01 & -3.72 & $25.51 * *$ \\
\hline JBGR- 1 X NBB - 1 & 2.88 & 10.36 & 6.75 & $8.81 * *$ & $-22.25^{* *}$ & -0.98 & $-26.04 * *$ & $22.75 * *$ \\
\hline JBGR- 1 X NSR - 1 & -3.96 & 14.39 & 7.12 & 3.26 & $-20.80 * *$ & 2.41 & $-14.75^{*}$ & $25.20 * *$ \\
\hline GBL - 1 X NSRP- 1 & -1.98 & 12.79 & 1.10 & $-8.05^{* *}$ & -1.38 & -1.12 & -2.97 & $11.84^{*}$ \\
\hline GBL - 1 X NBB - 1 & $8.94 *$ & $32.71 *$ & 12.04 & $-8.05^{* *}$ & 5.44 & $27.57 * *$ & 3.62 & 12.55 \\
\hline GBL - 1 X NSR - 1 & 6.25 & $26.96 * *$ & $19.05^{*}$ & 2.30 & $20.49 * *$ & $28.57 * *$ & 11.44 & 4.53 \\
\hline GJB - 2 X NSRP- 1 & 1.19 & $15.94 *$ & $13.61^{*}$ & $-5.75 * *$ & $-17.18^{* *}$ & 19.03 & $-23.93 * *$ & 10.38 \\
\hline GJB - 2 X NBB - 1 & -2.57 & 4.34 & 12.16 & 4.02 & -5.05 & 11.07 & $-35.87 * *$ & -1.82 \\
\hline GJB - 2 X NSR - 1 & -4.45 & -5.03 & 10.52 & 1.72 & 7.60 & $28.55 * *$ & -5.05 & 7.30 \\
\hline AB- 08 - 6 X NSRP- 1 & -5.08 & -6.55 & 10.17 & $-6.51 * *$ & -7.66 & -18.40 & $-17.56^{*}$ & -7.77 \\
\hline AB- 08 - 6 X NBB - 1 & -1.13 & 0.24 & $16.96^{*}$ & -1.53 & 0.47 & 2.33 & $-22.17 * *$ & 2.08 \\
\hline AB- 08 - 6 X NSR - 1 & $-10.25^{*}$ & $-15.78^{*}$ & -4.63 & $-5.75^{* *}$ & 0.44 & -9.97 & $-35.62 * *$ & 8.40 \\
\hline AB - 10- 14 X NSRP- 1 & 4.32 & $-18.70^{*}$ & -7.55 & 0.19 & $-23.26^{* *}$ & -16.81 & $-20.07 * *$ & $21.08 * *$ \\
\hline$A B-10-14$ X NBB - 1 & -7.35 & -0.29 & 2.42 & 3.07 & $-37.98 * *$ & -10.19 & $-15.02 *$ & $36.66 * *$ \\
\hline AB - 10- 14 X NSR - 1 & $-16.31 * *$ & 8.06 & 6.86 & 0.77 & $-10.95^{*}$ & -0.56 & $-27.41 * *$ & -8.66 \\
\hline AB - 09-1 X NSRP- 1 & $-19.25 * *$ & $21.10 * *$ & 8.96 & 1.92 & $31.57 * *$ & -3.42 & $-23.37 * *$ & $-24.23 * *$ \\
\hline AB - 09- 1 X NBB - 1 & 3.95 & $20.80 * *$ & $19.29 * *$ & 1.34 & $23.25^{* *}$ & $49.59 * *$ & $14.55^{*}$ & 5.84 \\
\hline AB - 09-1 X NSR - 1 & -9.32 & 5.73 & 4.28 & -4.02 & -9.62 & -10.40 & $-16.29 *$ & $14.72 *$ \\
\hline AB - 11- 8 X NSRP- 1 & -4.47 & 3.42 & 12.77 & -3.26 & -8.61 & -6.42 & $-14.89 *$ & $16.09 *$ \\
\hline$A B-11-8 \times$ NBB - 1 & 0.68 & $23.55 * *$ & -4.32 & -1.34 & $-38.12 * *$ & 15.63 & $-22.46 * *$ & $15.85^{*}$ \\
\hline AB - 11- 8 X NSR - 1 & -8.44 & 13.96 & 10.05 & 3.26 & $-11.46^{*}$ & -2.17 & -12.83 & 0.52 \\
\hline S.Em.+ & 0.51 & 3.4 & 0.84 & 0.58 & 4.20 & 0.58 & 0.64 & 1.25 \\
\hline CD@ $5 \%$ & 0.99 & 6.7 & 1.66 & 1.14 & 8.27 & 1.15 & 1.28 & 2.47 \\
\hline CD@ $1 \%$ & 1.31 & 8.8 & 2.19 & 1.50 & 10.19 & 1.51 & 1.69 & 3.25 \\
\hline
\end{tabular}

$*$ and ** Significant at $5 \%$ and $1 \%$ level of probability, respectively. 
Table.2 The estimation of standard heterosis over environments (pooled) for different characters

\begin{tabular}{|c|c|c|c|c|c|c|}
\hline HYBRIDS & 9 & 10 & 11 & 12 & 13 & 14 \\
\hline AB -07- 2 X NSRP- 1 & -1.88 & $-18.96 * *$ & $-24.48 * *$ & $-10.18 * *$ & $-20.77 * *$ & -2.16 \\
\hline AB -07- 2 X NBB - 1 & $-13.45^{*}$ & $-18.38 * *$ & $-32.90 * *$ & $-11.79 * *$ & $-18.32 * *$ & $9.33 * *$ \\
\hline AB -07- 2 X NSR - 1 & -6.75 & $-21.16^{* *}$ & $-8.02 * *$ & -6.55 & $-20.78 * *$ & -1.53 \\
\hline AB -08- 5 X NSRP- 1 & -6.57 & 0.36 & $18.26 * *$ & $7.69 *$ & $-23.13 * *$ & -0.77 \\
\hline AB -08- 5 X NBB - 1 & $-20.75 * *$ & 0.07 & $28.98 * *$ & -1.37 & $-22.68 * *$ & 1.25 \\
\hline AB -08- 5 X NSR - 1 & -6.74 & $-18.91 * *$ & $-5.73 * *$ & -1.67 & $-10.61 * *$ & $-7.12 *$ \\
\hline AB -08- 14 X NSRP- 1 & 2.80 & 0.00 & $11.35 * *$ & -2.03 & $-24.74 * *$ & $8.53 *$ \\
\hline AB -08- 14 X NBB - 1 & -5.92 & -6.78 & $-9.97 * *$ & -3.44 & $-24.03 * *$ & $7.78^{*}$ \\
\hline AB -08- 14 X NSR - 1 & -6.68 & $-12.34 * *$ & $-7.79 * *$ & $-10.16^{* *}$ & $-9.58 * *$ & $9.60 * *$ \\
\hline JBL -08- 08 X NSRP- 1 & 7.01 & 0.29 & 1.04 & 3.27 & $-15.77 * *$ & $12.17 * *$ \\
\hline JBL -08- 08 X NBB - 1 & -10.59 & 0.40 & $-17.95 * *$ & -4.01 & $-14.98 * *$ & 5.24 \\
\hline JBL -08- 08 X NSR - 1 & $33.47 * *$ & $-18.53 * *$ & $-11.03 * *$ & $17.46^{* *}$ & $-21.85 * *$ & $18.87 * *$ \\
\hline JBL -10- 04 X NSRP- 1 & -4.61 & $-19.25 * *$ & $-18.82 * *$ & -3.68 & $-31.46 * *$ & $10.42 * *$ \\
\hline JBL -10- 04 X NBB - 1 & $12.42 *$ & 1.37 & $-34.03 * *$ & -0.59 & $-17.89 * *$ & 4.45 \\
\hline JBL -10- 04 X NSR - 1 & $16.50 *$ & 0.13 & $-30.08 * *$ & -5.01 & $-10.90 * *$ & 1.70 \\
\hline JBGR- 1 X NSRP- 1 & $-15.49 *$ & 1.28 & $26.24 * *$ & $-22.80 * *$ & $-15.70 * *$ & 4.21 \\
\hline JBGR- 1 X NBB - 1 & -5.52 & $-18.58 * *$ & $5.29 * *$ & -5.68 & $-15.06 * *$ & $15.61 * *$ \\
\hline JBGR- 1 X NSR - 1 & -3.11 & $-19.16 * *$ & $-34.98 * *$ & $-24.34 * *$ & -0.28 & 1.82 \\
\hline GBL - 1 X NSRP- 1 & 7.85 & -0.99 & $-20.23 * *$ & 2.47 & $-14.33 * *$ & $10.76^{* *}$ \\
\hline GBL - 1 X NBB - 1 & $17.25 * *$ & -0.47 & $20.13 * *$ & -4.12 & -4.55 & $14.41 * *$ \\
\hline GBL - 1 X NSR - 1 & $23.52 * *$ & $-21.83 * *$ & $32.79 * *$ & 2.05 & $-14.56 * *$ & $24.58 * *$ \\
\hline GJB - 2 X NSRP- 1 & -9.99 & $-20.60 * *$ & $-28.94 * *$ & $-18.59 * *$ & $-16.36 * *$ & 2.91 \\
\hline GJB - 2 X NBB - 1 & -8.74 & $-19.83 * *$ & $-14.69 * *$ & $-13.35 * *$ & $-18.07 * *$ & $8.89 * *$ \\
\hline GJB - 2 X NSR - 1 & 9.45 & $-18.62 * *$ & $26.09 * *$ & -5.68 & $-9.62 * *$ & $7.34 *$ \\
\hline AB- 08 - 6 X NSRP- 1 & $-16.18 * *$ & 0.90 & $-32.36 * *$ & 1.12 & $-17.35 * *$ & 3.33 \\
\hline AB- 08 - 6 X NBB - 1 & 1.27 & $-18.29 * *$ & $18.58 * *$ & 2.68 & $-13.60 * *$ & 5.55 \\
\hline AB- 08 - 6 X NSR - 1 & 6.84 & $-18.44 * *$ & $18.24 * *$ & -7.20 & $-25.22 * *$ & 6.08 \\
\hline AB - 10- 14 X NSRP- 1 & -8.82 & $-19.07 * *$ & $15.12 * *$ & -5.51 & $-17.56 * *$ & $7.15^{*}$ \\
\hline AB - 10- 14 X NBB - 1 & $-15.63 * *$ & $-18.35^{* *}$ & $-21.20 * *$ & -3.85 & $-21.72 * *$ & -5.65 \\
\hline AB - 10- 14 X NSR - 1 & $-19.42 * *$ & $-27.31 * *$ & $21.42 * *$ & -7.04 & $-17.79 * *$ & -0.24 \\
\hline AB - 09-1 X NSRP- 1 & -2.00 & $-18.82 * *$ & $-36.31 * *$ & $-15.38 * *$ & $-25.50 * *$ & -2.07 \\
\hline AB - 09- 1 X NBB - 1 & $28.21 * *$ & $-19.86 * *$ & $6.04 * *$ & $-8.01 *$ & $-19.67 * *$ & $-9.33 * *$ \\
\hline AB - 09-1 X NSR - 1 & 1.92 & $-19.12 * *$ & $-31.55 * *$ & $-9.44 *$ & $-19.47 * *$ & $18.97 * *$ \\
\hline AB - 11- 8 X NSRP- 1 & 5.04 & -0.25 & $14.42 * *$ & 0.51 & $-9.18 *$ & 2.86 \\
\hline AB - 11- 8 X NBB - 1 & $-29.96 * *$ & $-38.57 * *$ & $-19.61 * *$ & -24.80 & $-14.33 * *$ & 4.94 \\
\hline AB - 11- 8 X NSR - 1 & $-11.84^{*}$ & $-21.49 * *$ & $2.60 *$ & -6.36 & $-28.63 * *$ & 1.31 \\
\hline S.Em.+ & 106.39 & 0.13 & 15.74 & 0.39 & 0.31 & 0.30 \\
\hline CD@ $5 \%$ & 209.57 & 0.26 & 31.04 & 0.77 & 0.63 & 0.59 \\
\hline CD@ $1 \%$ & 276.34 & 0.35 & 40.93 & 1.17 & 0.83 & 0.78 \\
\hline
\end{tabular}

$*$ and ** Significant at $5 \%$ and $1 \%$ level of probability, respectively. 


\section{Where,}

\begin{tabular}{|c|l|}
\hline Character No. & Name of the character \\
\hline $\mathbf{1}$ & Plant height $(\mathrm{cm})$ \\
\hline $\mathbf{2}$ & Seedling height $(\mathrm{cm})$ \\
\hline $\mathbf{3}$ & Number of branches per plant \\
\hline $\mathbf{4}$ & Days to 50 per cent flowering \\
\hline $\mathbf{5}$ & Average fruit weight $(\mathrm{g})$ \\
\hline $\mathbf{6}$ & Average fruit length $(\mathrm{cm})$ \\
\hline $\mathbf{7}$ & Fruit yield per plant $(\mathrm{g})$ \\
\hline $\mathbf{8}$ & Test weight $(\mathrm{g})$ \\
\hline $\mathbf{9}$ & Number of seeds per fruit \\
\hline $\mathbf{1 0}$ & Fruit dray matter $(\mathrm{g})$ \\
\hline $\mathbf{1 1}$ & Total soluble sugar $($ per cent $)$ \\
\hline $\mathbf{1 2}$ & Ascorbic acid $(\mathrm{mg} / 100 \mathrm{~g})$ \\
\hline $\mathbf{1 3}$ & Number of fruits per plant \\
\hline $\mathbf{1 4}$ & Average fruit diameter \\
\hline
\end{tabular}

Table.3 Promising hybrids for fruit yield per plant with standard heterosis, gca effects, sca effects and component traits showing significant desired heterosis based on pooled over environments

\begin{tabular}{|c|c|c|c|c|c|c|c|}
\hline \multirow{2}{*}{$\begin{array}{l}\text { Sr. } \\
\text { No. }\end{array}$} & \multirow[t]{2}{*}{ Hybrid } & \multirow{2}{*}{$\begin{array}{l}\text { Fruit yield } \\
\text { per plant } \\
\text { (g) }\end{array}$} & \multirow{2}{*}{$\begin{array}{l}\text { Standard } \\
\text { Heterosis } \\
\quad(\%)\end{array}$} & \multicolumn{2}{|c|}{ gca effects } & \multirow{2}{*}{$\begin{array}{c}s c a \\
\text { effects }\end{array}$} & \multirow{2}{*}{$\begin{array}{c}\text { Useful and significant for component } \\
\text { traits } \\
\text { Standard heterosis }(\%)\end{array}$} \\
\hline & & & & P1 & P2 & & \\
\hline 1. & $\begin{array}{l}\text { JBL-08- } \\
08 \quad x \\
\text { NSR-1 }\end{array}$ & 2636.98 & $33.47 * *$ & $228.22 * *$ & 92.50 & $371.92 * *$ & $\begin{array}{l}\text { Seedling height }(\mathrm{cm}) \text {, Plant height }(\mathrm{cm}) \text {, } \\
\text { Number of branches per plant, Average } \\
\text { fruit weight }(\mathrm{g}) \text {, Average fruit length }(\mathrm{cm}) \text {, } \\
\text { Number of fruits per plant, Fruit dry } \\
\text { matter }(\mathrm{g}) \text {, Total soluble Sugar (Per cent), } \\
\text { Ascorbic acid }(\mathrm{mg} / 100 \mathrm{~g}) \text {, Number of } \\
\text { seeds per fruit, Test weight }\end{array}$ \\
\hline 2. & $\begin{array}{l}\text { AB-09-1 } \\
\text { x NBB-1 }\end{array}$ & 2533.04 & $28.21 * *$ & $216.58 * *$ & 53.30 & $425.41 * *$ & $\begin{array}{l}\text { Plant height }(\mathrm{cm}) \text {, Number of branches per } \\
\text { plant, Average fruit weight }(\mathrm{g}) \text {, Average } \\
\text { fruit length }(\mathrm{cm}) \text {, Average fruit diameter } \\
(\mathrm{cm}) \text {, Total soluble sugar (per cent), Test } \\
\text { weight }(\mathrm{g}) \text {, Number of seeds per fruit }\end{array}$ \\
\hline 3. & $\begin{array}{l}\text { GBL-1 } x \\
\text { NSR-1 }\end{array}$ & 2440.40 & $23.52^{* *}$ & $351.55^{* *}$ & 92.50 & 52.01 & $\begin{array}{l}\text { Plant height }(\mathrm{cm}) \text {, Number of branches per } \\
\text { plant, Average fruit weight }(\mathrm{g}) \text {, Average } \\
\text { fruit length }(\mathrm{cm}) \text {, Total soluble sugar (per } \\
\text { cent), Ascorbic acid }(\mathrm{mg} / 100 \mathrm{~g})\end{array}$ \\
\hline 4. & $\begin{array}{l}\text { GBL-1 } x \\
\text { NBB-1 }\end{array}$ & 2316.45 & $17.25^{* *}$ & $351.55^{* *}$ & $\begin{array}{c}- \\
53.30\end{array}$ & 73.86 & $\begin{array}{l}\text { Seedling height }(\mathrm{cm}) \text {, Plant height }(\mathrm{cm}) \\
\text { Average fruit weight }(\mathrm{g}) \text { Average fruit } \\
\text { length }(\mathrm{cm}) \text {, Total soluble Sugar (per } \\
\text { cent), Ascorbic acid }(\mathrm{mg} / 100 \mathrm{~g}) \text {, Days to } \\
50 \text { per cent flowering, Test weight }(\mathrm{g})\end{array}$ \\
\hline
\end{tabular}


As everybody know that for processing purpose, the fruit should have a high dry matter contain (Dhruve et al., (2014)). For this trait positive heterosis was desirable. Among the top four higher yielding crosses, only one crosses JBL -08-08 x NSR-1 was exhibited positive and significant heterosis over check. The other three crosses dose not showed standard heterosis in desired direction indicated that these characters could not play vital role on fruit yield in brinjal. This findings are also in conformation with the reports of earlier workers Chadha et al., (1990) and Suneetha et al., (2008).

The developmental, morphological and some of the yield components like average fruit diameter and number of fruits per plant did not bear any relationship with fruit yield of brinjal in respect of heterotic effect, combining ability and stability. It limits the utility of these characters in identifying good combining parents and heterotic hybrids for future exploitation in breeding programme. The magnitude of heterosis for fruit yield components suggested the use of heterosis on commercial scale. The superiority of JBL-08$08 \times$ NSR- 1 in yield indicating that there might be possibility of exploiting the heterosis commercially after testing on large scale.

\section{References}

Ajjappalavara, P. S. (2006).Genetic studies and management of bacterial wilt in brinjal (Solanum melongena L.). Ph.D. (Agri.) Thesis, University of Agricultural Sciences, Dharwad.

Biswas, L., Mehta, N. and Ansari, S. F. (2013). Hybrid vigour study in brinjal (Solanum melongena L.). Global J. Sci. Frontier Res. Agri. and Vet., 13(9):7-11.

Chadha, M. L., Joshi, A. K. and Ghai, T. R. (1990). Heterosis breeding in brinjal. Indian J. Hort., 47(4):417-423.
Chowdhury, M. J., Ahmad, S. and Nazim, U. (2010). Expression of heterosis for productive traits in $\mathrm{F}_{1}$ brinjal (Solanum melongena L.) hybrids. The Agriculturist, 8(2):8-13.

Deshmukh, S. B., Narkhede, G. W., Gabale, L. K. and Dod, V. N. (2015). Hybrid vigour in brinjal (Solanum melongena L.). The Bioscan, 10 (2):869-876.

Dhruve, J.J., Rutika shah; Swati Gandhi and Talati, J. G. (2014) Biochemical and morphological traits of different cultivars of brinjal fruits growing in anand (Gujarat). Indian $J$ Agric Biochem., 27 (2), 211-214.

Fonseca, S. and Patterson, F.L. (1968). Hybrid vigour in seven parent diallel cross in common winter wheat (Triticum aestivum L.). Crop Sci., 8: 8588.

Hanson, P. M., Yang, R. Y., Tsou, S. C. S., Ledesma, D., Engle, L. and Lee, T. C. (2006). Diversity in eggplant (Solanum melongena L.) for superoxide scavenging activity, total phenolics and ascorbic acid. J. Food. Comp. Anal. 19 (6-7): 594-600.

Joshi, A. and Thakur, M. C. (2003). Exploitation of heterosis for yield and yield contributing traits in tomato (Lycopersicon esculentum Mill.). Progressive Horticulture, 35(1):64-68.

Kalaiyarasi G., S. Ram R R., Saravanan K. R. (2018). Studies on heterosis for yield in Brinjal (Solanum melongena. L). Horti. Biotech. Res., 4: 35-38.

Kamalakkannan, T., Karuppaiah, P., Sekar, K. and Senthilkumar, P. (2007). Line x Tester analysis in brinjal for yield and shoot and fruit borer tolerance. Indian J. Hort., 64 (4): 420-424.

Kumar, R. S., Arumungam, T., Anandkumar, C. R. and Rajavela, D.S. (2012). Estimation of heterosis and specific combining ability for yield, quality, pest and dieses incidence in eggplant 
(Solanum melongena L.). Env. Pharmacol. Life Sci., 2 (1):3-13.

Makani, A. Y., Patel, A. L., Bhatt, A. M. and Patel, P. C. (2013). Heterosis for yield and its contributing attributes in brinjal (Solanum melongena L.). The Bioscan, 8(4):1369-1379.

Nagai, K. and Kada, M. (1926). An experiment with some varietal crosses of eggplants. Japanese J. Gen., 4:10-30.

Pandey, M. and Yadav, G.C. (2018). Heterosis for earliness and yield contributing traits in brinjal (Solanum melongena L.). Int. J. Chem. Studies, 6(4): 232-234.

Pandey, S., Singh, B., Singh, M. and Rai, M. (2005). Heterosis in cucumber (Cucumis Sativus L.). Veg. Sci., 32 (2): 143-145.

Panse, V. G. and Sukhatme, P.V. (1978) "Statistical methods for agricultural workers" I.C.A.R, New Delhi.

Prabakaran, S. (2010). Evaluation of local types of egg plant (Solanum melongena L.). M.Sc., (Hort.) thesis, Agricultural College and Research Institute, TNAU, Madurai.

Prabhu, M., Natarajan, S. and Pugalendhi, L. (2005). Studies on heterosis and mean performance in brinjal (Solanum melongena L.). Veg. Sci., 32(1):86-87.

Pramila, Kushwaha, M.L. and Singh,Y. P. (2017). Studies on heterosis in Brinjal (Solanum melongena L.). Int. J. Curr. Micro. App. Sci., 6 (11): 641-65.

Ramani, P. S., Vaddoria, M. A. and Patel, J. B. (2015). Heterosis for fruit yield and its component traits in brinjal (Solanum melongena $\quad$ L.). $\quad$ AGRES-An
International e-J., 4 (3):249-254.

Reddy, E. E. P. and Patel, A. I. (2014). Studies on gene action and combining ability for yield and other quantitative traits in Brinjal (Solanum melongena L.). Trends in Biosciences, 7(3):381383.

Sasikumar, A. (1999) Screening of eggplant (Solanum melongena L.) genotypes for quality and yield. M.Sc., (Hort.) Thesis, Tamil Nadu Agricultural University, Coimbatore.

Sao, A. and Mehta, N. (2010). Heterosis in relation to combining ability for yield and quality attributes in brinjal (Solanum melongena L.). Ele. J. Pl. Br., 1(4):783-788.

Sharma T. K., Pant S. C., Kumar K., Kurrey V. K., Pandey P. K. and Bairwa P. L. (2016). Studies on heterosis in Brinjal (Solanum melongena L.). Int. J.Bioresource and Stress Management, 7 (5):964-969.

Suneetha, Y., Kathira, K. B., Patel, J. S. and Srinivas T. (2008). Studies on Heterosis and combining ability in late summer brinjal (Solanum melongena L.). Indian J. Agric. Res., 42 (3): 171-176.

Thakur, A. K., Kholi, U. K. and Joshi, A. (2004). Evaluation of diallel progeny and heterosis for yield and yield components in tomato (Lycopersicon esculantum Mill.). Haryana. J. Horti. Sci., 33(1\&2): 106-108.

Yordanor, M. (1983). Heterosis in tomato. In Monographs on Theoretical and Applied Genetics, Ed. Frankel, R., Springer Verkg, Berlin, pp. 187-219.

\section{How to cite this article:}

Chaudhari, B. N., A. I. Patel and Vashi, J. M. 2020. Study on Heterosis over Environments in Brinjal (Solanum melongena L.). Int.J.Curr.Microbiol.App.Sci. 9(07): 3358-3367. doi: https://doi.org/10.20546/ijcmas.2020.907.392 